\title{
Byelorussian Orthography: from the 1933 Reform to the Present Day
}

\author{
BY \\ P. J. MAYO
}

I

The foundations of the grammatical and orthographical systems of the modern Byelorussian literary language were laid by B. Taraškievič in his Biełaruskaja hramatyka dla škot, the first edition of which was published in Vilna in 1918. At that time the grammar and orthography of literary Byelorussian were characterised by a considerable degree of arbitrariness. There were no officially codified norms and it was not yet clear which dialect would emerge as the basis of the literary language. The normative influence of such publications as Naša niva, which played a major role in the standardisation of the alphabet, was much less evident in the spheres of grammar and orthography. Out of this situation of 'škodny chaos' (to borrow a phrase which he was to use later in a different context), Taraškievič created order. Acknowledging the need for a period of flexibility to allow the most suitable dialect base to be chosen for the literary language, he felt that the time had now come to make a choice. Biełaruskaja hramatyka dla šlkot was based on what Taraškievič regarded as the most characteristic dialect of Byelorussian, namely that with hard [r] and strong akannie; a decade later, in the foreword to the fifth edition of his grammar, Taraškievič wrote that he had seen its task as being 'to consolidate and regularise... the grammatical basis of the Byelorussian literary language and to establish a permanent orthography'. ${ }^{1}$

Almost half a century later still we can see that Biełaruskaja hramatyka dla škot substantially succeeded in those aims. That is not to suggest that there have been no significant changes in the grammatical and orthographical norms of Byelorussian during that time. Quite apart from the natural evolution of the language, despite the general excellence of Taraškievič's grammar and its widespread adoption in the decade following its publication, it was inevitable that, in what was the first systematic grammar of modern Byelorussian, some problems should have been resolved less than satisfactorily. If one adds to this the interference of political considerations, especially in the 1930 s, it is immediately obvious that the

\footnotetext{
1. B. Taraškievič, Bietaruskaja hramatyka dla škol, 5th edition, Vilna, 1929, pradmova.
} 
Byelorussian literary language of today will in certain respects differ noticeably from Taraškievič's conception of it.

Nowhere is this more evident than in the orthography. Throughout the 1920s proposals to introduce certain reforms into Taraškievič's orthography, principally in the areas of jakannie and the treatment of loan-words, occupied much of the attention of scholars of Byelorussian. A number of articles on orthographical topics appeared in the journals Potymia and Uzvyšs̆a." In 1926, largely at the instigation of the main proponent of substantial reform, Jazep Losik, the Scientific Council of the Institute of Byelorussian Culture called an Academic Conference on the Reform of the Byelorussian Orthography and Alphabet. ${ }^{3}$ As a result of the discussions at this conference a Commission on the Literary Language was created which in turn appointed an Orthographical Commission to look into the questions raised. The culmination of all this activity was the publication in 1930 by the Academy of Sciences of a plan (prajekt) for the orthography of Byelorussian which incorporated some of the changes proposed at the 1926 conference. ${ }^{4}$

The prajekt was never put into practice. Instead in 1933 the Council of People's Commissars published a decree entitled Ab źmienach $i$ spraščenni bietaruskaha pravapisa." It is true that in a number of important respects (e.g. the restriction of jakannie to the immediate pre-tonic syllable, the retention of unstressed e, 9 in loan-words, various rules concerning the orthography of proper names and toponyms) the decree incorporated changes which had been put forward also by the authors of the 1930 prajekt, but this was largely incidental. By this time political considerations had superseded linguistic ones; many of the members of the Orthographical Commission which had produced the 1930 prajekt were regarded as ideological heretics and had been exiled or imprisoned, accused of that most heinous of crimes 'bourgeois nationalism'. The introduction to the 1933 decree certainly leaves us in no doubt as to their 'crime':

'Byelorussian national democracy, proceeding from its bourgeois, counter-revolutionary aims, has carried out its subversive saboteurs' work on both the economic and the cultural front, including the sphere of language, terminology and orthography. National democracy has striven by all means possible to divorce the Byelorussian literary language from the language of the broad working masses, erected an artificial barrier between the Byelorussian and Russian languages and contaminated the Byelo-

2. Ja. Losik, 'Neǔstanoŭlenyja vypadki našaha pravapisu', Potymia, 2, 1924; A. Bahdanovič, 'Da pytańnia ab neŭstanoŭlenych vypadkach našaha pravapisu', ibid., 7,1925 ; S. Niekraševič, 'Ab pašyreńni akańnia na čužazlemnyja słovy', ibid., 5, 1926; A. Losik, Ja. Losik 'Da reformy biełaruskaha pravapisu', ibid., 6, 1926; 'U. Duboǔka, 'Pra našu litaraturnuju movu', Uzvyšša, 2, 1927; 'Niekatoryja pryvatnyja vypadkı miłahučnaści našaje movy', ibid., 4, 1927; 'Padoǔžanyja (abo padvojnyja) zyěnyja 1 sposab ich aznaCeńnia na piśmie', ibid., 2, 1929; $V$. Volsk1, 'Da pytańnia pra sproščnaje aznačeńnie padvojnych zyčnych na piśmie', ibid., 4. 1929.

3. The proceedings of this conference were published as Pracy Akademicnaje konferencyi pa reformie bietaruskaha pravapisu $t$ azbuki (14-21 listapada 1926 h.), Inbierkult, Minsk, 1927.

4. Bielaruski pravapis (prajekt), AN BSSR, Minsk, 1930.

5. Zviazda, 26 August 1933. For a detailed discussion of the 1926 conference, the 1930 prajekt and the 1933 decree see: P. J. Mayo, "The Alphabet and Orthography of Byelorussian in the 20th Century', $J B S$, vol. IV, No. 1, London, 1977, pp. 28-48. 
russian language with various medieval archaisms and bourgeois vulgarisms.' ${ }^{6}$

nor as to the political nature of the reforms themselves:

'With the aims of the decisive eradication from Byelorussian orthography of national-democratic influences and distortions, the facilitation of the learning of written Byelorussian by the working masses, the liberation of the school from unproductive labour in connection with the study of Byelorussian orthography, with the aims of the further development of the culture of the Byelorussian language and the complete subordination of Byelorussian orthography to the tasks of educating the working masses in the spirit of proletarian internationalism, the Council of People's Commissars of the BSSR decrees the introduction into the existing orthography of the following reforms ...7

Part of the process of breaking down the 'artificial barrier' between Russian and Byelorussian was the introduction of a number of orthographical and morphological changes by means of which Byelorussian words would acquire an appearance identical with or very similar to that of corresponding Russian words. The most blatant example of this in the orthography was the creation of a special category of 'international-revolutionary words' (e.g. рэволюцыя, совет, комунізм) to be exempt from the normal rules of akannie. Russification was also in evidence in the rules concerning the treatment of foreign $l$ as predominantly hard, of foreign $s, z$ as predominantly soft ${ }^{8}$ (both of which were alien to Byelorussian practice and tradition), but above all in the changes in the morphology - the spread of the ending -a $(-g)$ in the genitive singular of masculine nouns of the second declension at the expense of $-y(-\circ)$; the abolition of the stressed endings -óm, -óx in the dative and locative plural of masculine and neuter nouns and their replacement by the endings -ам, -ax; the unification of the oblique cases of the numerals два (абодва) and дзве (абедзве) by the abolition of the formerly distinct feminine forms and of the alternative masculine and neuter forms with the stem vowel o, leaving only those forms which coincided with the Russian forms (двуx, двум, двума); the standardisation of the ending of the second person plural of the present tense of first conjugation verbs, regardless of whether they were stressed on the stem or the ending; the replacement of the stressed ending of the second person plural of the imperative mood éце (-э́це) by the ending -íце (-б́це); and, finally, the exhortation 'to introduce into the orthography (sic) of Byelorussian active participles, especially when they have a social meaning'.9

Some of the morphological characteristics of Byelorussian abolished by the 1933 decree were subsequently restored by the Pastanova $A b$ udałıladnieńni i častkovych źmienach isnujučaha biełaruskaha pravapisu, published by the Council of Ministers of the BSSR in 1957, but

\footnotetext{
6. Ab żmienach i spraščenni bietaruskaha pravapisa, Pastanova Savieta Narodnych Kamisaraŭ BSSR, reproduced in T. P. Eamcioŭ, Bietaruskaja hramatyka. Fanietyka $i$ pravapis, Minsk, 1935 , p. 67.

7. ibid., p. 68 .

8. ibid., p. 69

9. ibid., p. 71 .
} 
this new decree contained only minor amendments to the orthography. The changes introduced in 1933 remain substantially in force to the present day, and are codified in the official handbook of modern Byelorussian orthographical and punctuational norms (Pravity biełaruskaj arfahrafii $i$ punktuacyi) published by the Academy of Sciences in 1959.

The definitive rules laid down in 1933 have thus with the passage of almost half a century acquired a degree of permanency and respectability. What this surface situation conceals, however, is a continuing concern, and in many instances dissatisfaction, with the orthographical norms of modern Byelorussian. Leaving aside for the moment the understandable and to some extent predictable attitude of non-Soviet Byelorussians, we find that this concern has manifested itself within Soviet Byelorussia at three stages in particular: in 1933$39,1946-48$ and again in 1951-52.

\section{II}

The 1933 decree took effect from 16 September of that year; from that date schools and publishing houses were to adopt the new orthography. Grammars and textbooks incorporating and applying the new rules were needed and a number were published over the next few years. ${ }^{10}$ Towards the end of the 1930 s, however, it was becoming clear that not for everyone in Soviet Byelorussia had the 1933 decree succeeded in its stated aims. Dissatisfaction with some aspects of the decree surfaced publicly in articles which appeared in Zviazda, Litaratura i mastactva and Sovetskaja Belorussija in 1938 and 1939.

There was a certain irony in the fact that almost all the authors of these articles accused the authors of the 1933 decree of the same 'crime' against which the latter had themselves inveighed so heavily, and called for further reforms which would bring Byelorussian even closer to Russian.

The first shot in the campaign was fired in an article which appeared in Zviazda on 9 April 1938. ${ }^{11}$ Less than five years after the introduction of substantial changes in the orthography of Byelorussian the author of the article, K. Hurski, a 'scientific worker' (navukovy rabotnik) at the Academy of Sciences in Minsk, called for a fundamental reform which would rid Byelorussian orthography of what he termed 'the subterfuges and incongruities introduced by the enemies of the people'. For Hurski the term 'enemies of the people' embraced not only those who had been actively concerned with orthographical problems in the 1920 s, but also those who had produced the 1933 decree. The former, according to Hurski, had been responsible for 'putting a brake on the development of the Byelorussian language and retarding the achievement of universal literacy'. This should have been put right in 1933 but the enemies of the people were still in powerful positions in the Academy of Sciences and other

\footnotetext{
10. Eamcioŭ, op. cit.; N. I. Seŭčyk, A. S. Sołomienik, Hramatyka bietaruskaj movy, Minsk, 1935; Bietaruskaja hramatyka. Marfatohija (ed. T. P. Eamcloŭ), Minsk, 1936; Ju. A. Sakal, M. I. Zyrklevič, Hramatyka, I, Minsk, 1938.

11. K. Hurski, 'Ab bielaruskim pravapisie'.
} 
leading institutions and had used their position to do even more damage, with the result that 'not only was there not a real purge of Byelorussian orthography, but on the contrary, under the guise of amendments the agents of fascism had dragged into the orthography a whole series of harmful and inimical distortions and in a number of places had further complicated it'. What Hurski meant by this was not those changes in the orthography (and morphology) which had had the effect of blurring the distinction between Byelorussian and Russian, but those sections of the 1933 decree which dealt with the orthography of foreign names and toponyms i.e. precisely those aspects of the decree which showed the least evidence of Russification. Like the authors of the 1933 decree Hurski talked of the need to pull down the 'artificial barrier' between Byelorussian and Russian, but he went further than his predecessors. He advocated the achievement of this aim by means of the total rejection of the phonetic principle in the orthography of vowels in Byelorussian i.e. the abolition of akańnie and jakannie, though he could find no better justification for his proposal than that akannie in Byelorussian hindered pupils in their study of Russian!

The hysterical political tone of Hurski's article was echoed in a number of others. Articles by P. F. Chadarenka, ${ }^{12}$ M. N. Karpačoŭ, ${ }^{13}$ P. Dzik ${ }^{14}$ (all in Zviazda) and by V. Borisenko ${ }^{15}$ (in Sovetskaja Belorussija) all opened with characteristic diatribes against the 'enemies of the people'. All four writers also echoed Hurski's rejection of the phonetic principle, Chadarenka associating it, even more directly than Hurski had done, with the same 'enemies of the people'.

Dzik, in particular, abhorred the phonetic principle and in addition to the abolition of akannie and jakannie wanted to see the extension of the morphological principle in other areas of the orthography e.g. through the retention of the voiced consonant 3 at the end of prefixes, regardless of whether the following consonant was voiced or unvoiced.

Both Dzik and Karpačoŭ highlighted one area of confusion which the 1933 decree (and, indeed, the 1930 prajekt before it) had failed to deal with. This was the inconsistency in the application of dziekannie and ciekannie to loanwords or native words formed on foreign roots. Thus Sakał and Žyrkievič's Hramatyka (1938) recommended the spellings камандзір but камандыроўка, without attempting any explanation or offering any guide-lines. This inconsistency was to be resolved only with the publication of the 1957 decree, which recommended the application of dziekannie and ciekannie in words of foreign origin which had the Byelorussian suffixes -iн, -ip, -ëp, -еец, -ейск, -ік. ${ }^{16}$

Otherwise Dzik, Karpačoŭ and Chadarenka focused their attention mainly on morphological matters. Chadarenka was concerned at what he regarded as unnecessary proliferation of the characteristic first

12. 'Patrebna nieadkładnaje spraščeńnte biełaruskaha pravapisu', Zviazda, 6 July 1938.

13. 'Mai zaŭvahi', ibid.

14. 'Da pytańnia ab sučasnaj biełaruskaj arfahrafii', ibid., 16 October 1938.

15. 'O projekte reformy belorusskogo pravopisanija', Sovetskaja Belorussija, 16 February 1939.

16. See M. I. Hurski, M. H. Bułahaŭ, M. C. Marčanka, Bietaruskaja mova, 1. Leksikatohija, fanietyka $i$ marfatohija, Minsk, 1961, p. 114. 
declension ending in the instrumental singular of third declension nouns (е.g. крывёю, гразёю, плыняй in addition to кроўю, граззю, плынню). Dzik and Karpačoŭ, on the other hand, were more concerned to propose changes which would bring Byelorussian grammar more into line with Russian: Dzik wanted more use of participles and of the suffix -ip- in verbal borrowings (е.g. тэлетрафіраваць cf. Russian телеграфировать - instead of тэлеграфаваць etc.) while Karpačoŭ regarded the ending $-\mathrm{y}(-\circ)$ in the genitive singular of masculine nouns of the second declension as archaic and anachronistic, preferring $-\mathrm{a}(-\mathrm{r})$ in all instances, and also advocated the use of the genitive singular case after the numerals $2,3,4$.

Borisenko's article in Sovetskaja Belorussija contained some curious inconsistencies. Writing in much the same vein as the authors mentioned above, he nevertheless managed at the same time to see the separation of the group of 'international-revolutionary' words from the normal rules of akannie as a plot, not to give such words a more Russian appearance, but to present them as 'absolutely foreign to Byelorussian, as alien words which had not arisen in the language itself in the course of its historical development. In this way enemies wished to present revolutionary concepts as alien, imposed on the Byelorussian people'. Indeed, Borisenko's whole approach to the idea of a new orthography was contradictory: on the one hand he wanted it to reflect 'all the characteristics and riches of the living Byelorussian language', while on the other hand it should strengthen the links between Byelorussian, Ukrainian and Russian by bringing them closer together.

Like Hurski before him, Borisenko stimulated a response in the form of further articles. ${ }^{17}$ The authors of these, while rejecting Borisenko's call for the abolition of akannie, nevertheless proposed a number of other changes in the orthography which, although this was not explicitly stated, would have the effect of further Russifying Byelorussian. Thus M. A. Raščenja called for the abolition of prothetic $в$, $і$ and $a$, the retention of $в$ in syllable final position (e.g. головка, травка), and the use of $\mathbf{b}$ instead of the apostrophe; while A. K. Bondarenko favoured the eradication of jakannie and the preservation of д, т in the groups здн, стл, стн (cf. the normal Byelorussian spelling позні, чэсны, шчаслівы with Russian поздний, честный, счастливый).

Sovetskaja Belorussija also received a number of letters in response to Borisenko's article and on 3 June 1939 published a survey of the points raised in them. ${ }^{18}$ According to the editors of Sovetskaja Belorussija the majority of readers reacting to Borisenko's article wanted not just partial changes in the orthography laid down in 1933, but a fundamental reappraisal. Most correspondents agreed with Raščenja and Bondarenko in favouring the retention of akańnie, although they were happy to accept the abolition of jakannie. There appears also to have been considerable support for the retention of $\breve{y}$ only

\footnotetext{
17. M. A. Raščnja, 'Reforma belorusskogo pravopisanija neobkhodima', Sovetskaja Belorussija, 5 March 1939; A. K. Bondarenko et al., 'Nabolevšlje voprosy belorusskogo pravopisanija', 1bid., 9 April 1939.

18. 'O reforme belorusskogo pravopisanija (obzor pisem)', ibid., 3 June 1939.
} 
internally in a closed syllable (contrast Raščenja who wanted to abolish the change of ${ }_{B}>\breve{y}$ precisely in this position) and for the generalisation of the ending $-\mathrm{a}(-\mathrm{-})$ in the genitive singular of masculine nouns of the second declension.

In contrasting tone to all the articles mentioned so far was one by S. Hryščuk, published in Litaratura $i$ mastactva in $1939^{19}$, which contained none of the propagandistic rantings of the articles by Hurski, Dzik etc. For Hryščuk the only 'artificial barrier' was the one that existed between Byelorussian pronunciation and orthography, and he came out strongly in favour of the phonetic principle in the spelling of vowels. Despite his general affirmation of the phonetic principle, however, and a desire to see akannie appled to the "international-revolutionary' words, Hryščuk took the same line as Raščenja and Bondarenko in supporting the eradication of jakannie from the orthography. His reason for this was one of simplification: such a change would bring native and loan-words under one general rule. Among a number of other minor proposals, some of which amounted in fact to no more than a reaffirmation of existing rules, Hryščk also advocated dziekańnie and ciekannie in loan-words which had soft $[\mathrm{d}$,$] or [\mathrm{t}$,$] in the language of origin, citing as examples such$ possible spellings as дзірэктар, дзелегат, ціф, эпіцет and пацефон.

Hryščuk's article was, however, exceptional in being based entirely on linguistic arguments. Thirty years later the excesses of Hurski, Dzik, Borisenko and others were to be excused by the authors of the second volume of Historyja bielaruskaj litaraturnaj movy on the grounds that the discussion took place in a historically complex period when in the fierce ideological struggle attempts were made to consider the maintenance of national linguistic differences as a means of separating nations. ${ }^{20}$ Whether one regards this as sufficient justification or not, it was perhaps fortunate for Byelorussian that some of the proponents of reform went to such extremes, since this almost certainly rendered their proposals ineffectual. When, in 1941, the Academy of Sciences published its Kurs sučasnaj biełaruskaj movy, ${ }^{21}$ it showed no concessions to the views expressed during the 'debate' of 1938-39.

\section{III}

Further discussion and/or implementation of any of the orthographical changes suggested in the late 1930s was also hindered by the outbreak of war and the Nazi occupation of Byelorussia. At the same time opponents of the 1933 reform, both from within and without the Soviet Union, seized the opportunity to increase their own propaganda for the restoration of pre-1933 norms.

19. 'Zaŭvahi ab biełaruskim pravapisie', Litaratura $i$ mastactva, 3 July 1939.

20. Historyja bietaruskaj litaraturnaj movy, II [by I. I. Kramko, A. K. Jurevič, A. I. Janovič], Minsk, 1968, p. 273.

21. K. I. Hurski, T. P. Łamcioŭ, T. Z. Sklar, S. L. Rochkind, Kurs sučasnaj biełaruskaj movy. Fanletyka. Marfalohija. Leksika, Minsk, 1941. 
The 1933 decree had, of course, from the very beginning evoked a hostile response from linguists in non-Soviet Byelorussia, a response which was exemplified in the publication of a protest against the reforms by the Byelorussian Scientific Society in Vilna..2 One of the most vociferous opponents of the 1933 decree in Western Byelorussia was Janka Stankievič who in 1936 published a pamphlet denouncing the reforms and the motives behind them ${ }^{2: 3}$ and was to remain a critic, both theoretical and practical, over the next quarter of a century. ${ }^{24}$

The year 1935 saw the beginning also of regular gatherings of Byelorussian linguists, philologists, writers, poets and editors who were concerned with what they called the purity (čyścinia) of the Byelorussian language. The culmination of these meetings was the publication in Prague in 1941 of a pamphlet entitled Jak pravilna havaryć i pisać pabiełarusku (Pastanovy Zborkaŭ Čyścini Biełaruskaje Movy). This pamphlet, published under the general heading of 'Byelorussian Correspondence Courses in Prague' contained an appeal to the Byelorussian intelligentsia to support their work by implementing their resolutions in their own speech and writing; it was not a systematic description of Byelorussian but consisted simply of random observations on points of phonetics, morphology and lexis. It had very little to say explicitly on the subject of the orthography, although it implicitly supported the pre-1933 norms in the form of the orthography in which it was printed e.g. b was retained after $3, \mathrm{c}$, дз, I before a soft consonant and between 'double' consonants, jakannie was reflected where appropriate in the particle не/ня and the preposition без/бяз.

Of potentially greater significance as far as the orthography was concerned was the publication in 1943 of Anton Losik's Bietaruski pravapis, in both Latin and Cyrillic script. Published in Minsk under German occupation and approved for use in Byelorussian national schools by the Generalkommissar für Weissruthenien Losik's book sought to re-establish the orthographical norms of the 1920s, but with an admixture of his own proposals and those put forward (with little success) by his brother Jazep at the 1926 Academic Conference on the Reform of the Byelorussian Orthography and Alphabet. ${ }^{25}$ Thus he reinstated dissimilative jakannie in the second pre-tonic syllable e.g. бядуна́, няшыро́кі, лясьнікі́ but селяні́, верабе́й, цесьлярыг; ${ }^{26}$ the reflection of jakannie in the particle не and the preposition без е.g. ня ве́даю, ня была́, бяз кні́гі, бяз сумле́ньня but не хачу́, без цяля́ці; 27 the indication of the sof tness of $3, c$, $ц$ before other soft consonants (except velars) e.g. зьмена, зьвер, сьнег, сьляза, цьвіце, цьвет but згінуць,

22. Pratest Biełaruskaha Navukovaha Tavarystva proci dekretu Savietu Narodnych Kamisaraŭ BSSR ab reformie bietaruskaha pravapisu, Vilna, 1933.

23. Ja. Stankievič, Zmiena hramatyki bielaruskaha jazyka u BSSR, Vilna, 1936.

24. See his Padrucnik kryvickaje (bietaruskaje) movy, Regensburg, 1947; 'Moŭnaja palityka balšavikoŭ u Biełaruskaj SSR', Bietaruski zbornik, 2, Múnich, 1955, pp. 49-110. and 'Niekatoryja novyja źmieny biełaruskaje narmatyŭnaje hramatyki i pravapisu u Bielaruskaj SSR', ibid., 7, Munich, 1957, pp. 153-63.

25. See Pracy Akademicnaje konferencyi ... p. p. IX, 184-208.

26. A. Losik, Bielaruski pravapis, Minsk, 1943, pp. 5-6 (This and all subsequent references are to the Cyrillic edition).

27. ibid., p. 6 . 
схіліць, скінуць ${ }^{28}$ and of the initial consonant in so-called 'double' consonants e.g. гразьзю, заданьне, калосьсе, жыцьцё еtc. ${ }^{29}$ and in disagreement, incidentally, with his brother Jazep's view ${ }^{30}$ - the spellings гарадзкі, людзкі, шведзкі, францускі, ческі, каўкаскі еtс. (instead of гарадскі, людскі, шведскі, французскі, чешскі, каўказскі). ${ }^{31}$ In all these areas Losik's orthographical rules coincided with those to be found in Taraškievič's grammar. ${ }^{32}$

Additionally, however, Anton Losik introduced an orthographical rule which ran counter to both pre- and post-1933 norms: there should be no change of $y$ to $\breve{y}$ in word initial position or when $y$ was an independent word. One should therefore write было улетку, бралі удзел, была у нас, кніга у мяне. ${ }^{33}$ This change in the orthography, which was completely alien to Byelorussian pronunciation and to the phonetic principle on which the orthography of vowels in Byelorussian had traditionally been based, was one which Jazep Losik had advocated strongly at the 1926 conference on the orthography. ${ }^{34}$ It had received no support from the other contributors and had been rejected by the ad hoc orthographical commission which sat at the end of that conference but not, strangely enough, by the more formally constituted Orthographical Commission of the Institute of Byelorussian Culture of the Academy of Sciences which produced the 1930 prajekt. The latter in fact recommended the retention of $y$ (and i) in all positions, ${ }^{35}$ although some members of the Commission (notably Niekraševič and Kupała) dissented from that view. ${ }^{36}$

Losik's orthography also re-established the morphological norms which had been violated by the 1933 decree: the use of the ending $-y(-\circ)$ in the genitive singular of masculine nouns of the second declension for a wide range of nouns for which the 1933 decree had recommended the ending -a(-я) e.g. інстытуту, універсітэту, правапicy; $;$ the stressed endings -óm, -óx in the dative and locative plural of masculine and neuter nouns; ${ }^{38}$ the distinction in the oblique cases of the numerals два and дзьве between the masculine and neuter forms on the one hand, and the feminine on the other, and the alternative forms for all three genders with the stem vowel 0 ;9 $^{\mathbf{3}}$ the differentiation in the ending of the second person plural of the present/future tense of first conjugation verbs between those with stem stress and those with the stress on the final syllable of the ending e.g. бу́дзеце, пішаце, несяце́, бераце́, (несяцё, берацё); ${ }^{40}$

28. ibtd., p. 12.

29. ibid., p. 15.

31. A. Losik, op. cit., pp. 12-13.

32. See Tarašklevič, op. cit., pp. 111, 55-6, 120 and 121 respectively.

33. A. Losik, op. cit., p. 7.

34. See Pracy Akademičnaje konferencyi . . , pp. IX, 206.

35. Bietaruski pravapis (prajekt), p. 13

36. ibid., pp. 49, 51.

37. A. Losik, op. cit., pp. 19-20. In this respect he went further than Tarašktevič had by attempting to define the semantic categories of nouns taking the ending -y(-ю) as well as of those taking -a (-s).

38. ibid., p. 23 .

39. ibtd., p. 29.

40. ibid., p. 33 . 
and the stressed ending of the second person plural of the imperative mood in -éце, i.e. нясе́це, бярз́це. ${ }^{41}$

On the orthography of loan words Losik proposed akannie but no jakańnie ${ }^{42}$ soft $\pi$ in word initial position or internally within a word, with a choice between $\pi$ and $\pi b$ in word final position, according to pronunciation in the language of origin e.g. стыль, аўтамабіль but капітал; ${ }^{43}$ Greek $\Phi$, Latin ph, and $\mathrm{f}$ to become $\phi$ e.g. філозофрія, факт, тарыф, Greek $\Theta$ and Latin th to become т е.g. тэатар, катэдра, with the proviso that in words which had long been assimilated by Byelorussian $\phi$ should be replaced by $\Pi, \mathbf{x}, \mathbf{x в , ~ е . g . ~ П і л і п , ~ х у н т , ~}$ хварба. ${ }^{44}$ Finally there were separate rules for the spelling of proper names and toponyms depending on their origin - Byelorussian, other Slavonic, non-Slavonic. ${ }^{45}$

Losik's orthography enjoyed only a brief reign. The liberation of Byelorussia and the re-establishment of Soviet rule put an end to all attempts to revert to pre-1933 orthographical conventions, although they continue to be observed by many Byelorussians living outside the Soviet Union, particularly in Canada and the United States.

\section{IV}

Within the Soviet Union the end of the war was the signal for Byelorussian linguists to turn their attention once again to the vexed question of orthographical reform. This renewed interest in orthographical problems found its first expression in a discussion article by M. R. Sudnik published in Nastaŭnickaja hazieta in $1946 .{ }^{46}$ For the first time since 1933 it was recognised that rules of language should not be artificially imposed from outside or thought up by scholars but should be based on the realities of usage.

Like others before him, Sudnik was concerned as much with the morphology of Byelorussian as with its orthography. Although he made some proposals for reform his article consisted mainly in a statement of the problems. In the sphere of orthography these continued to be the spelling of loan-words and in particular the question of how far they should be adapted to Byelorussian orthographical norms, of compound words and of proper names and toponyms. Sudnik favoured dziekannie and ciekannie in loan-words where this was consistent with a soft consonant in the language of origin (e.g. мініацюра, цюльпан), pointing out that such forms already existed in Byelorussian, albeit to a limited extent (cf. эцюд); the reflection of akannie in compound words according to the basic form (nominative singular of the appropriate gender) of their constituent parts e.g. свой + часовы $=$ своечасовы, добры + быт $=$ добрабыт, чорнае +

41. ibid., p. 34 .

42. ibid., p. 41.

43. ibid., p. 44 .

44. ibid.

45. ibid., pp. 45-7.

46. M. R. Sudnik, 'Da pytańnla ab biełaruskim pravapisie', Nastaŭnickaja hazieta, 16 May 1946. 
вока $=$ чорнавокі; and the adaptation of proper names and toponyms to conform to standard Byelorussian orthographical norms e.g. Чарнышэўскі, Арол, Адзеса etc. In addition Sudnik proposed an end to the practice of treating 'international-revolutionary' words as a special category where akannie was concerned and the introduction of prothetic в before unstressed vowels as well as stressed ones.

In response to Sudnik's article a number of others appeared in Nastaünickaja hazieta in the succeeding months. ${ }^{47}$ In general the authors of these articles agreed on the need for reform in the areas outlined by Sudnik and supported his particular proposals. The exception was Karpačoŭ who, though in less virulent terms than in 1938 , opposed the idea of any major reform and was not convinced of the importance of the phonetic principle in the spelling of vowels.

The theme of reform was taken up again in 1948 in an editorial article in Litaratura $i$ mastactva. ${ }^{48}$ This was a response to letters which the editorial board had received complaining about inconsistent orthographical usage in newspapers, magazines and other publications. Once again the major problems were identified as the spelling of loan-words and of proper nouns and toponyms. The division of the latter into Byelorussian and non-Byelorussian was regarded as artificial and spelling 'according to nationality' had only led to confusion. Equally artificial was the separation of native words and loan-words when it came to the reflection of akannie. The editors of Litaratura $i$ mastactva concluded with an appeal to linguists, writers and teachers both in higher educational establishments and in schools to come forward with practical proposals on the various points of contention in the orthography. The Institute of Language, Literature and Art of the Byelorussian Academy of Sciences should then, taking any discussion into account, prepare draft proposals for reform.

Both these things happened. Later in 1948 Litaratura $i$ mastactva published two articles which contained specific proposals on the orthography of loan-words. ${ }^{49}$ The authors of both these articles agreed on the extension of akannie to all loan-words, including the so-called 'international-revolutionary' words, with only very minor exceptions (e.g. радіо, оксо). They also favoured dziekannie and ciekańnie in loan-words, although the authors of one of the articles, S. Turčynovič and B. Piatrovič, wanted hard д, т to be retained before the vowel [ $\epsilon$ ]. On the extension of jakannie to loan-words, however, they disagreed. Turčynovič and Piatrovič were of the opinion that such forms as мятодыка, дазяртыр etc. would be artificial and likely to distort sense, claiming that while there was general agreement among linguits on the reflection of akannie this was not true for jakańnie. V. Važnik, on the other hand, saw no objection to subjecting loan-words to the same rules as native words where jakannie was concerned.

This once again highlighted the considerable division of opinion

47. M. N. Karpačoŭ, 'Hłyboka vyvučać movu naroda', ibid., 30 May 1946; P. Dubovik, S. Seŭ̌uuk, 'Źmieny nieabchođny', ibid., 13 June 1946; A. Barysavlec, 'Bolš dakładnaści', ibid., 18 July 1946.

48. 'Ab bielaruskim pravapisie', Litaratura i mastactva, 31 July 1948.

49. S. Turæ̌ynovið̌, B. Piatrovič, 'Inšamoŭnyja i internacyjanalna-revolucyjnyja słovy', ibid., 25 September 1948; V. Važnik, 'Suprać štuěnaści ŭ napisanni inšamoŭnych słoŭ' ibid., 20 November 1948. 
which has existed over jakannie in all discussion of Byelorussian orthographical norms this century, not only with regard to its application to loan-words but to native ones as well. One thinks, for instance, of the conflicting views on this subject expressed at the 1926 Academic Conference on the Reform of the Byelorussian Orthography and Alphabet, of the calls for the abolition of jakannie in the late 1930s (see above) and again in the discussion which followed the publication in 1951 of the Prajekt źmien $i$ udakiadnieńniaŭ biełaruskaha pravapisu.

Meanwhile the first orthographical dictionary of modern Byelorussian had been published. ${ }^{50}$ Compiled by M. R. Sudnik and M. P. Eoban, it unfortunately did little to remedy the situation since it was based on the norms of the 1933 decree and as a result perpetuated many of the less satisfactory aspects of that decree. Indeed Sudnik implicitly acknowledged as much in reiterating his dissatisfaction with a number of the norms on which the dictionary was based in an article published two years later..$^{51}$

The debate continued and in 1950 an Orthographical Commission, headed by Jakub Kołas and Kandrat Krapiva, was set up. In March of that year it held a conference to discuss a draft reform of the orthography, thus fulfilling the suggestion made by Litaratura $i$ mastactva two years earlier, and this draft was eventually published in Nastaŭnickaja hazieta on 9 August 1951.

\section{V}

In emphasising that a single orthographical principle should govern the treatment of both native words and loan-words the authors of Prajekt źmien $i$ udakładnieńniaŭ pravapisu identified the main source of the inconsistency and uncertainty which had bedevilled modern Byelorussian orthography ever since Taraškievič, in the first edition of .his Biełaruskaja hramatyka dla škot, had attempted to separate loan-words into those which had long been assimilated into Byelorussian (and were therefore to be spelt according to the normal orthographical rules) and those which were current in the literary language but had not penetrated the vernacular or had only recently done so. ${ }^{52}$ Such a division was inevitably subjective and as a result created considerable problems for those involved in teaching the language. In Krapiva's words:

'With us loan-words enjoy extraterritorial rights. They are subject to the laws of our morphology but do not recognise the laws of phonetics - therefore, on being introduced into the Byelorussian language they do not merge with it completely but follow their own individual course, and where there is a substantial concentration of them, lend our language an uncharacteristic sound.' 53

50. M. R. Sudnik, M. P. Łoban, Arfahrafičny stoŭnik, Minsk, 1948.

51. M. R. Sudnik, 'Da pytańnia ab historyi farmiravańnia biełaruskaj arfahrafienaj sistemy', Vieści Aḱademii Navuk BSSR, 3, 1950, pp. 46-57 (especially pp. 53-7).

52. Bietaruskaja hramatyka dla škot, 1st edition, Vilna, 1918, p. 102

53. K. K. Krapiva, 'Pytańni biełaruskaha pravapisu ŭ śviatle vučeńnia I. V. Stalina ab movie', Vieści Akademii Navuk BSSR, 2, 1952, p. 27. 
The 1933 decree had done nothing to remedy the situation; to overcome the artificial division between native words and loan-words the prajekt therefore proposed extending akańnie, and dziekannie and ciekannie where appropriate, to all loan words. This meant that the so-called 'international-revolutionary' words would cease to be distinguished by okańnie; 54 for the first time unstressed 9 in loanwords would also be subject to akannie, though the prajekt was less than consistent here since it made quite a number of exceptions (e.g. рэкорд, шэдэур) and indeed, in a few instances, for native words as well (е.g. выпэцкаць, шераваты). The extension of dziekańnie and ciekańnie in loan-words also presented problems, since there was no clear guidance as to when it was considered appropriate beyond the statement that when $д$ and $T$ were pronounced soft they should become дз, ц.

In order to eliminate confusion over jakannie the authors of the prajekt were in favour of its complete eradication both from loanwords and native words. As has already been mentioned and as we shall see from the reactions to the prajekt this was the most hotly disputed of all its recommendations.

The other main source of discontent with the existing orthography was the spelling of compound words. Here the prajekt set out a rule for the reflection of akannie on the same basis as that suggested by Sudnik in 1946 i.e. etymological o, э should be written in the first element of a compound word if it is present in the basic form (nominative singular) of that element when standing as an independent word, but not otherwise. This would give such spellings as моваве́д (cf. мова), мэтанакірава́насць (cf. мэта) but вадаправо́д (cf. вада). There were, however, a number of qualifications and exceptions to the rule and the resultant complexity was another of the chief targets of criticism in the published reactions to the prajekt.

The prajekt also set out rules governing the use of the apostrophe and the soft sign after hard and soft consonants before a jotated vowel. In 1933 this separating role had been allocated almost exclusively to the apostrophe, the only exception being the use of $\mathrm{b}$ after $\pi$; now the writing of $\mathbf{b}$ was recommended after four additional consonants - c, 3, ц, дз.

The close link between orthographical and grammatical reforms which had been a feature of the 1930 prajekt, the 1933 decree and almost all subsequent discussion was again reflected in the 1951 prajekt in a number of recommendations for changes in the morphology of Byelorussian. Principal among these were the following: a redefinition of the criteria determining the use of the endings $-a(-q)$ and $-y(-I 0)$ in the genitive singular case of masculine nouns of the second declension under which $-\mathrm{a}(-\mathrm{-})$ would be used for all nouns denoting individual units, $-\mathrm{y}(-\circ)$ for the remainder (nouns denoting materials and substances, collectives, natural phenomena, processes, various abstract intellectual concepts etc.); the standardisation of the

54. According to Sudnik (Vieści Akademii Navuk BSSR, 3, 1950, p. 54) there were eleven words in this category: совет, большевік, пролетарыи, рэволюцыя, комуна, комунізм, соцыялізм, комсамол, піонер, Комінтэрн, Профінтэрн. 
ending -ей(-эй) in the genitive plural of third declension nouns; the restoration of the differentiation in the endings of the first and second person plural of the present/future tense of first conjugation verbs between those with stem stress (-ем, -ам, -еце, -аце) and those stressed on the ending (-ём, -ом, -яце́, -аце́); a strict delineation between those same first person plural endings and those of the first person plural of the imperative mood (-е́м, -э'м); and the restoration of the distinctive oblique case forms of the feminine numeral дзве (абедзве) - дзвюх, дзвюм, дзвюма (абедзвюх еtc.).

The publication of the prajekt provoked wide-ranging discussion; at regular intervals for the rest of 1951 Nastaŭnickaja hazieta devoted considerable space to the reactions of teachers and scholars from a variety of educational institutions at both the secondary and tertiary levels. Together with these reactions the prajekt was the subject of a special conference devoted to questions of contemporary Byelorussian orthography which was held in the newly established Institute of Linguistics of the Byelorussian Academy of Sciences in Minsk on 2526 January 1952.

In the published reactions to the prajekt there was general support for the application of a single principle to both native and loan-words although, as B. Piatrovič pointed out, 55 this raised a dilemma in the case of jakannie, since the recommendation that this should not be reflected orthographically meant in effect that a native characteristic was being subordinated to a foreign one, something which he regarded as methodologically incorrect, and yet the alternative - extending jakannie to all loan-words - would lead to spellings which would not only obscure etymology but would also, paradoxically, be alien to Byelorussian.

As in previous discussions of orthographical matters it was the question of reflecting or not reflecting jakannie which created the sharpest division of opinion. The authors of the articles published in Nastaŭnickaja hazieta were divided approximately equally between those who supported the recommendation for the retention of unstressed $\mathrm{e}$ in the immediate pre-tonic syllable and those who rejected it.

Of the former group several supported the prajekt's recommendation as part of a general plea for the extension of the morphological (or etymological) principle at the expense of the phonetic - though none was so consistent as to call also for the eradication of akańnie from the orthography! M. Zyyrkievič claimed that only the extension of the morphological principle could give Byelorussian 'greater stability and consistency';6 while the joint authors of another article, S. Umrejka, I. Vadejka and M. Suler, expressed even stronger support for the morphological principle. ${ }^{57}$ The latter, respectively the director, deputy director and a senior research worker of the Byelorussian Ministry of Education's Pedagogical Research Institute, based their view on the results of a survey conducted for the Ministry of Education in 1949 among

55. B. Piatrovie, 'Zaŭvahi ab prajekcie', Nastaŭnıckaja hazłeta, 23 August 1951.

56. M. Zyrklevič, 'Likvidavaé niedachopy isnujučaha pravapisu', ibid., 13 December 1951.

57. S. Umrejka, I. Vadejka, M. Suler, 'Pašyryćc marfałahičny pryncyp u biełaruskim pravapisie', ibid., 13 September 1951. 
departments of Byelorussian language in various pedagogical institutions. Most replies had favoured the eradication of jakannie from the orthography, some (e.g. that of Baranavičy Teachers' Institute) echoing the view prevalent in the 1930s that Byelorussian orthography should be brought as close as possible to that of Russian, which was, of course, based almost entirely on the morphological principle. Apart from this the main reasons given for the retention of $e$ in all unstressed syllables were that jakannie was not a feature of all dialects of Byelorussian (this was disputed by supporters of the phonetic principle), that many recently adopted words did not reflect it and, somewhat illogically, that an extension of the phonetic principle in this area would necessitate (sic) the creation of a large category of exceptional forms alongside those which already existed cf. дзевяты, дзесяты, еднацца. Some (e.g. the Department of Byelorussian Language at Homiel Pedagogical Institute) wanted to go even further and eradicate $\mathrm{A}$ from a number of endings in which it had become morphologised, notably the adjective endings -яга, -яму, -яй, -ыя, -ія and the ending -яй in the instrumental singular case of first declension nouns with non-final stress.

Those who took the opposite view were, in general, strong supporters of the phonetic principle, certainly as far as the orthography of vowels was concerned. Je. Dubroŭskaja, Je. Niadźvieckaja and Z. Zyhałka saw it as the basic principle of Byelorussian orthography and jakannie as a characteristic feature of Byelorussian 'which knows no exception in any dialect'. ${ }^{88}$ This view was also shared by P. Pranuza, ${ }^{59}$ P. Dziubajla 60 and A. Saternik ${ }^{61}$ — indeed, the latter devoted the whole of his article to a plea for the retention of jakannie in the orthography, pointing out that problems in this connection arose not through writing $\Omega$ in the immediate pre-tonic syllable, but through the fact that there were numerous exceptions to this rule, especially among loan-words. Piatrovič, on the other hand, was not worried by these exceptions; to him there was nothing unnatural in the fact that jakannie was not applied to such words as герой, пнеўматыка, сентэнцыя - which orthographical system does not make exceptions for at least some words of foreign origin? ${ }^{62}$ It was precisely this reasoning that led many of those who were in favour of jakannie being reflected (at least in native words) to object to the prajekt's recommendation that akannie in the case of unstressed $э$ be extended from native words to loan-words. Yet there was a contradiction here; many of these same people were among those who strongly advocated a unified approach to all words, whatever their origin. ${ }^{63}$

Inconsistency was also evident in the reaction to the prajekt's recommendation that 'international-revolutionary' words should no longer be treated as a special category exempt from the normal rules

58. Je. Dubroŭskaja, Je Niadźvieckaja, Z. Zyhałka, 'Naši zaŭvah1', ibid., 20 September 1951. 59. P. Pranuza, 'Za adnastajnaść i dakładnasć hramatyčnych aznačeńniaŭ', ibid., 22 November 1951.

60. P. Dziubajla, 'Udakładnić biełaruski pravapis', ibid., 11 October 1951.

61. A. Saternik, 'Zachavać pryncyp jakańnia', ibid., 22 November 1951.

62. Piatrovic, op cit.

63. See, for example: N. Hurski, 'Pytańni arfahrafii biełaruskaj movy', ibid., 23 August 1951; Piatrovic, op. cit. 
of akannie: it was welcomed by supporters of both the phonetic and morphological principles in the orthography of vowels. Furthermore, those who spoke out strongly against it on the grounds that as things stood these words were closer to Russian were equally strongly in favour of the retention of jakańnie as a fundamental trait of Byelorussian! ${ }^{64}$

With the recommendation that dziekańnie and ciekannie be extended to loan-words there was general agreement, though the authors of some of the articles were not happy with the prajekt's formulation and wanted a clear definition of where this would apply and, in some cases, detailed lists of exceptions. ${ }^{65}$ Similar dissatisfaction was expressed over the imprecise formulation of rules for the spelling of compound words and for the use of the apostrophe and soft sign; there was a general feeling that the recommendations in the prajekt only served to further complicate an already confusing situation.

If reactions to the prajekt's recommendations relating specifically to the orthography can be seen to have covered a fairly wide spectrum, the same cannot be said of reactions to those relating to the morphology of Byelorussian. With only the occasional exception there is a striking unanimity of attitude, a unanimity in favour of accepting or, in most cases, rejecting the prajekt's recommendations so as to preserve or even increase the orientation of the Byelorussian literary language towards Russian.

Nowhere was this more evident than with regard to the ending of the genitive singular case of masculine nouns of the second declension. The prajekt's redefinition of the criteria governing the choice of the ending $-\mathrm{a}(\mathrm{A})$ or $-\mathrm{y}(-\mathrm{-O})$ satisfied none of the contributors to the debate; all wanted to see the ending $-\mathrm{a}(-\mathrm{a})$ regarded as the norm and $-y(-ю)$ as exceptional and limited to certain categories which should be listed, ${ }^{66}$ while I. Savicki went so far as to suggest that a formulation should be devised which would coincide with the situation in Russian. ${ }^{67}$

There was a similar rejection of the prajekt's proposed changes in the endings of the present/future tense and imperative mood of first conjugation verbs, with only one dissenting voice.68 These were regarded as artificial, especially the proposal to introduce distinctive endings in the first person plural of the imperative mood. Russian, of course, makes no distinction in the first person plural between the present/future tense and imperative mood, and both Piatrovič and Žyrkievič attacked the prajekt's recommendation on the grounds that it would only tend to isolate Byelorussian from Russian.69 On the other hand, the proposed unification of the genitive plural of third declension nouns by the absolute use of the ending -ей (-эй) met with no opposition, and it is surely not without significance that this, the

64. Pranuza, op. cit.; Dubroŭskaja, Niadźvieckaja, Žyharka, op. cit.

65. N. Hurski, op. cit.; Zyrkievič, op. cit.

66. Umrejka, Vadejka, Suler (op. cit.) listed these categories as nouns denoting: abstract intellectual concepts, substances, collectives, motion, grammatical concepts.

67. I. Savick1, 'Niekalk1 zaŭvah' Nastaŭntckaja hazieta, 22 November 1951.

68. A. Vieramiejcyk, 'Prajekt pavińien byé udakładnien', ibłd., 25 October 1951.

69. Piatrovič, op cit.; Ž̀rkievič, op. cit. 
only proposal in the prajekt concerning morphological change which was generally approved, was also the only one which, if adopted, would bring Byelorussian more into line with Russian, although this does not necessarily imply that it was made with that intention.

The proposal to reintroduce the distinctive oblique case forms of the feminine numeral дзве (абе,лзве) attracted little attention and was referred to by the authors of only two articles: Dziubajla approved ${ }^{70}$ but Žyrkievič, in keeping with his general preference for changes which erased the differences between Byelorussian and Russian, considered it 'unnecessary'.i1

The articles published in Nastaŭnickaja hazieta, together with communications sent directly to the Institute of Linguistics of the Byelorussian Academy of Sciences, convinced the Orthographical Commission responsible for the prajekt of the need to call another conference to discuss further the problems of reforming the orthography. This conference was held in the Institute of Linguistics on 25-26 January 1952 and among the contributors were Jakub Kołas, Kandrat Krapiva, P. Ja. Jurhilevič, P. F. Hlebka, from Russia V. V. Vinogradov, V. I. Borkovskij and R. I. Avanesov, and from the Ukrainian Academy of Sciences I. N. Kiričenko. ${ }^{72}$

The opening speech, by Jakub Kołas, was followed by a paper from Vinogradov with the rather wordy title 'The tasks of Soviet science in the sphere of language in the light of the works of comrade Stalin on problems of linguistics' - (it was, after all, less than two years since the appearance of Stalin's Marksizm i voprosy jazykoznanija). The key speech, however, was that made by Krapiva, which was published soon afterwards as an article in Vieści Akademii Navuk BSSR.7:3

In his speech Krapiva summarised and categorised the views which had been and were still being put forward both on the general problem of orthographical reform and, specifically, in relation to the recommendations of the 1951 prajekt. Of the need for some kind of reform nobody appeared to be in doubt; it was also generally agreed that the root cause of most of the current confusion and lack of consistency in orthographical matters was the conflict between the two major principles of the orthography - the phonetic and the morphological (etymological). To quote Krapiva:

'The phonetic principle, on which the orthography of Byelorussian is largely based, does not extend to all categories of words. In one instance the rules of Byelorussian orthography are applied to the total vocabulary, both native and foreign, without exception; in another with considerable exceptions; in yet a third to all the vocabulary from the East Slavonic languages; in a fourth instance only to Byelorussian words. And since

70. Dziubajla, op cit.

71. 'Zyrkievič, op cit.

72. For a summary of the proceedings of this conference see I. A. Ossovetskij, 'Voprosy sovremennoj belorusskoj orfografii', Voprosy jazykoznanija, 2, 1952, pp. 151-5.

73. K. K. Krapiva, 'Pytańni bielaruskaha pravapisu ù śviatle vučeńnia I. V. Stalina ab movie', Vieści Akademii Navuk BSSR, 2, 1952, pp. 24-37. In more recent times this has been reprinted, without the references to Stalin, as 'Pytańni biełaruskaha pravaplsu' e.g. in Kandrat Krapiva, Zbor tvoraŭ, vol. 5, Minsk, 1976, pp. 170-88. Further references are to this edition. 
it is impossible to separate all these categories of words one from another in a clear-cut way, even highly literate people, i.e. people who are extremely familiar with the existing orthography, write the same words in different ways'. ${ }^{74}$

When it came to finding a way out of this situation, however, there was much less agreement. Broadly speaking, opinion was divided into two camps: those who favoured extension of the morphological principle and, conversely, those who supported a more consistent application of the phonetic principle. The most extreme proponent of the former was Jurhilevič, of the Mahiloŭ Pedagogical Institute, who advocated the total abolition from Byelorussian orthography of akańnie, jakańnie, dziekańnie and ciekannie. Fortunately there was little support for such a drastic upheaval even among those who were generally in favour of some extension of the morphological principle, and Krapiva himself rejected it on the grounds not only that it would constitute too great an upheaval, but also that it would divorce the literary language from the vernacular, that the whole tradition of Byelorussian was against it and that in many instances it was no longer possible to establish the etymological origins of words. ${ }^{75}$ At the other end of the spectrum there were those (e.g. Satermik) who advocated the extension of the phonetic principle to all loan-words, which would result in such unfamiliar spellings as сязон, шадзеўр, равалюцыя, цяорыя, цяатр. In producing the Prajekt źmien $i$ udakładnieńniaŭ biełaruskaha pravapisu the Orthographical Commission had steered a middle course between these two extremes by recommending the general application of akannie to both native and loan-words (with only minor exceptions) but at the same time the eradication of jakannie from native words so that there would be no contradiction between the spelling of these and of loan-words (which had always preserved unstressed $e$ in the immediate pre-tonic syllable).

In the remainder of his speech Krapiva re-examined the individual recommendations put forward by the Orthographical Commission in the light of subsequent discussion in the press and elsewhere. Perhaps unsurprisingly for one of the authors of the prajekt he saw no reason to change his mind about any of the proposals, although he did concede that, as had been pointed out by many of the contributors to the debate, the formulation of the recommendations regarding the extension of dziekannie and ciekannie to loan-words, the orthography of compound words and the choice between the endings $-a(-r)$ and $-y(-\circ)$ in the genitive singular of masculine nouns of the second declension was less than satisfactory. In the case of the last of these he offered a simplification of the rule which was effectively a rebuttal of those (e.g. Umrejka, Savicki, Žyrkievič) who wanted the ending -a $(-я)$ to be regarded as basic and $-y(-\circ)$ as exceptional. Krapiva's proposal was that $-a(-g)$ should be limited to nouns in two categories: 1) those which denoted animate beings and 2) those which could be

74. Krapiva, op cit., p. 172.

75. ibid., pp. 172-3. 
combined with пay̆ and the things denoted by them considered ar units. All other nouns would take the ending -y $(-\circ) .^{\mathbf{7 6}}$

After Krapiva's speech the conference was given over to c discussion of the prajekt and its individual recommendations. Mosi speakers simply reiterated viewpoints which had already been taken into account in the drafting of the prajekt and in Krapiva's reexamination of it. One significant point which did emerge, however, was the intensity of feeling that existed against the proposal to eradicate jakannie from the or thography of native words. This was exemplified in the contribution by $N$. T. Vajtovič, of the Minsk Pedagogical Institute, who made a strong plea for its retention on the grounds that jakannie, of various types, was (like akannie) a characteristic of almost all dialects of Byelorussian and, in particular, strcng jakaínie was a feature of the central dialects i.e. those dialects which formed the basis of the literary language. Such a fundamental characteristic of Byelorussian should therefore find expression in the orthography in some form. The retention of jakarinie was defended by a number of other speakers, among them A. Ja. Birała, M. C. Marčanka and A. Barysaviec, and I. A. Ossovetskij, in his report of the conference for Voprosy jazykoznanija, recorded that Vajtovič's speech 'reflected the point of view of the majority of speakers'.77

In his closing speech Krapiva, recognising that it was that section of the prajekt which dealt with akannie and jakannie that had gencrated the most disagreement, promised that the views expressed would be taken into account by the Orthographical Commission in its continuing work on the prajekt.

After the conference little else appeared in print on the subject of the orthography. In February 1952 Litaratura $i$ mastactva published articles by Krapiva ${ }^{78}$ and Avanesov $^{79}$ but neither of these added anything new, indeed Krapiva's article was simply taken verbatim from the introductory part of his conference speech and dealt only with the general principles governing orthographical reform. Five years were to elapse before the appearance of the long-awaited new decree on the orthography of Byelorussian.

\section{VI}

When it was finally ratified by the Soviet of Ministers of the BSSR on 11 May 1957 the decree Ab udakładnieñni $i$ častkovych źmienach isnuiučaha bietaruskaha pravapisu ${ }^{80}$ endorsed many of the proposals put forward in the 1951 prajekt. Akannie was extended to the 'international-revolutionary' words, to initial unstressed o in proper names and toponyms, to final unstressed o in indeclinable loan-words (except those in which o followed a vowel e.g. трыо, Tokio), and to unstressed $\ni$ in proper names and toponyms of Slavonic origin; dziekańnie and ciekannie were extended to words of foreign origin with the Byelorussian

76. ibid., p. 185.

77. Ossovetskij, op cit., p. 154

78. Krapiva, 'Ab pryncypach udakładnieńnia bielaruskaha pravapisu', Litaratura i mastactva, 9 February 1952.

79. R. I. Avaniesaŭ, 'Pytańni biełaruskaha pravapisu', tbid., 23 February 1952.

80. The decree was first published in Zviazda, 23 May 1957 and in Litaratura $i$ rnastactva, 25 May 1957. 
suffixes -ін, -ip, -ёр, -еец, -ік, -ейскі е.g. каранцін, камандзір, акцёр, індзеёц, білецік, гвардзейскі; the change of initial в $>$ y before a consonant was extended to proper names and toponyms e.g. Уладзімір, Уладзівасток; the particles бы(о) and ж(жа) were to be written without a hyphen attaching them to the preceding word. In the sphere of morphology the characteristic Byelorussian forms of the first and second person plural of the present/future tense of first conjugation verbs with final stress were restored e.g. бяром, оераце́, нясём, несяце́, as was the delineation between the endings of the first person plural of the present/future tense and the corresponding endings of the imperative mood (бярэм, нясем), and the distinctive feminine oblique case forms of the numeral дзве (абедзве).

With regard to jakannie, the orthography of compound words, the use of the apostrophe and soft sign and the sphere of usage of the ending $-y(-\circ)$ in the genitive singular of masculine nouns of the second declension. the rules in the decree differed considerably from the original recommendations of the 1951 prajekt.

Apparently taking cognisance of the strength of the reaction against the prajekt's proposal for the complete eradication of jakannie from the orthography of Byelorussian, the decree in fact extended the reflection of jakannie in the immediate pre-tonic syllable, but only to names and toponyms of Slavonic origin or which had long been assimilated into Byelorussian. The same rule, incidentally, was applied to akannie in the case of unstressed 3 . While the retention of jakannie in native words is to be applauded in the sense that it preserved a characteristic distinguishing feature of Byelorussian, it is unfortunate that its extension (and that of akannie in the case of unstressed 9) was limited in this way, since it contravened one of the basic principles underlying the reform, namely that there should be as little differentiation as possible in the treatment of native words and loan-words. Where previously it had been necessary to distinguish orthographically between native words on the one hand and loan-words on the other, it was now necessary to take account of the origin of borrowed vocabulary and distinguish between Slavonic e.g. Нява, Чарнышэўскі, and non-Slavonic e.g. сезон, Неапаль, шэдэўр, Шэкспір.

Criticism of the prajekt's proposal for the spelling of compound words was answered in the decree by the adoption of a more formal criterion - the position of the stress in the second element. Compound words in which the stress fell on the first syllable of the second element were to be regarded as single-stress words and akannie reflected accordingly e.g. вадаспа́д, галавало́мка, паляво́д; where the stress fell on some other syllable of the second element the compound word was to be treated effectively as two words, with secondary stress on the first element e.g. чо́рнавало́сы, бóекампле́кт, шыро́каэкра́нны. This rule was, however, subject to a number of qualifications, chief among them being that unstressed 9 in the first element was to be preserved regardless of the position of the stress e.g. шэраво́к:, and that in portmanteau words o, a, e, я in unstressed position were to be written as in the original full form e.g. кона́pмiя 
(cf. конская армія), камсамо́л (cf. камуністычная моладзь). As a result the decree was hardly more satisfactory in terms of simplicity than the recommendation in the 1951 prajekt had been.

On the use of the apostrophe and soft sign to separate a consonant from a subsequent jotated vowel the decree took a different and more complex approach than that of the prajekt. The latter had simply proposed that the apostrophe be used after all consonants except $\pi, \mathrm{c}$, 3, ц, дз, after which $\mathbf{b}$ was to be used. The decree introduced the following rule: the apostrophe was to be used after all prefixes ending in a consonant e.g. аб'ява, раз'юшаны and also internally in a word after the labials, velars, chuintantes and the liquid p е.g. сям'я, Лук'янаў, Буш'е, бар'ер; the soft sign after the consonants л, н, с, ц, дз аnd з (not in a prefix) in words of foreign origin e.g. вальера, каньяк, канферансье, парцьеры, мадзьяр, Карбюзье.

The decree did not implement the prajekt's recommendation that there should be a redefinition of the criteria determining the use of the endings $-a(-g)$ and $-y(-\circ)$ in the genitive singular of masculine nouns of the second declension; equally it did not show any concession to the many voices raised in the discussion of the prajekt in favour of treating $-\mathrm{y}(-\circ)$ as exceptional and limiting it to a few well-defined categories. The task of semantic categorisation was left to the Academy of Sciences' Hramatyka biełaruskaj movy, which appeared some five years later; ${ }^{81}$ instead the decree contented itself with extending the use of the ending $-y(-ю)$ to nouns denoting chemical elements and compounds e.g. кісляроду, азоту, амонію.

Finally, one recommendation from the 1951 prajekt was totally ignored by the 1957 decree: the proposal to standardise the ending of the genitive plural of third declension nouns as -ей (-эй).

The decree came into effect on 1 January 1958 but was not implemented in schools and higher educational establishments until 1 September, the beginning of the new academic year. Within Soviet Byelorussia it appears to have provoked no critical reaction; the only article on the subject to appear in print at that time was simply an explanatory survey of the points in the decree together with some historical background to the reforms, ${ }^{82}$ though some dissatisfaction was expressed with their presentation in Pravity biełaruskaj arfahrafii i punktuacyi two years later. ${ }^{83}$

The decree's reception outside the Soviet Union was less assured. Although those aspects of it which undid some of the 'damage' done in 1933 met with approval, there was still a feeling that it had not gone far enough in that direction. Once again Janka Stankievič was not slow to put his views into print: in 1957 he published a detailed survey of the individual points of the decree ${ }^{84}$ and, while cautiously welcoming one or two of them (the extension of the ending $-y(-10)$ in the genitive singular of masculine nouns of the second declension to

81. Hramatyka bietaruskaj movy, 1. Marfatohtja, Minsk, 1962, pp. 48-51.

82. M. Łoban, 'Novaje ŭ bielaruskim pravapisie', Litaratura $i$ mastactva, 1 June 1957.

83. H. Klusaŭ, 'Daviednik patrabuje udakładnieńniaŭ i dapracovak', Narodnaja asvieta, 2 , 1961, pp. 78-86.

04. Stankievič, 'Niekatoryja novyja źmieny biełaruskaje normatyŭnaje hramatyki i pravapisu ü bielaruskaj SSR', Bietaruski zbornik, 7, Munich, 1957, pp. 153-63. 
those denoting chemical elements and compounds and the restoration of the distinctive oblique case forms of the feminine numeral дзве) made it clear that nothing less than the complete rejection of the reforms introduced in 1933 would have satisfied him. While it is possible to sympathise with this view it is difficult, when one examines all the evidence, to agree with his conclusion, reached with a certain amount of tortuous logic, that the 1957 decree served only to 'further Russify Byelorussian grammar and orthography.' ${ }^{85}$

\section{VII}

The two decades that have elapsed since the publication of the 1957 decree have been a period of consolidation. In 1959 the official handbook of the orthographical and punctuational norms was published; ${ }^{\mathbf{8}}$ 1961 saw the appearance of a new orthographical dictionary, further editions of which have appeared at regular intervals since; ${ }^{87}$ a number of textbooks have been produced in which the principles of Byelorussian orthography are expanded in greater detail and their assimilation facilitated by illustrative exercises. ${ }^{88}$

The existing orthography is thus by now well-established and a return to pre-1933 norms seems to the author of this article neither practicable nor desirable. Nevertheless a number of inconsistencies remain and these it would be possible to eliminate without recourse to major revision.

Firstly, and most importantly, jakannie should be reflected in loanwords as well as native ones. This would eradicate a major inconsistency which has been recognised by many who have contributed to the debate on orthographical reform over the years, but has never been resolved. The 1951 prajekt did, it is true, offer an alternative solution in proposing the total elimination of jakannie from the orthography, but how much better it would be to solve the problem while still preserving what is, after all, a fundamental distinguishing feature of Byelorussian. It has been argued that to do so would obscure the etymology of the loan-words concerned; logic would demand that the same objection be raised to the reflection of akannie in loan-words yet this has never been the case. Akannie in loanwords, in the case of unstressed o at least, has, in varying degrees, been a feature of Byelorussian since Taraškievič's day and exceptions to this rule are now confined to a very small area (final unstressed o after a vowel). By the same token akańnie should be extended to unstressed $\boldsymbol{3}$ in all loan-words.

Secondly, there is even less justification for the retention of unstressed $e$ in the immediate pre-tonic syllable of the numeral-words дзевяты, дзесяты, семнаццаць (семнаццаты), васемнаццаць (васемнаццаты), пяцьдзесят, пяцідзесяты, шасцідзесяты, сямідзесяты

85. ibid., p. 163 .

86. Pravity bietaruskaj arfahrafii $i$ punktuacyi, AN BSSR, Minsk, 1959.

87. M. P. Łoban, M. R. Sudnik, Arfahrafičny stoŭnik dla siaredniaj škoty, Minsk, 1961; 2nd edition, 1966; 3rd edition, 1971.

88: Notably those by Ja. M. Kamaroŭski: Biełaruski pravapis, Minsk, 1965 and Bietaruskaja mova. Arfahrafija, Minsk, 1972. 
and васьмідзесяты, since these contravene even the existing rule.

Thirdly, since akannie in the case of unstressed o is applied to both native and loan-words, it seems unnecessary to make a distinction between final unstressed o after a consonant (e.g. брута, нета) and after a vowel (e.g. трыо, Токіо).

Fourthly, in compound words in which the stress is on the first syllable of the second element there is no secondary stress. The whole is treated as a single word subject to the normal rules of akannie but only in the case of unstressed $o$. Unstressed 9 in the first element of such compound words is preserved. Again there seems to be no justification for the differentiation between on the one hand чópнaвало́сы but чарнавóкі, and on the other hand мэтанакірава́насць and мэтазго́дны.

Finally, there is one inconsistency which, unlike the above, has gone unremarked since the 1930 prajekt: the orthographical representation of the non-syllabic sounds [w] and [j] deriving from $[\mathrm{u} / \mathrm{v} / \mathrm{l}]$ and [i] following a vowel. Whereas [w] is reflected in the orthography in all instances as y̆ (е.g. за ўсё, прыехалі ў горад, праўда, чытаў), [i] is shown as й only internally in a word (e.g. свойскі) or in word final position (e.g. людзей) but not in initial position (e.g. яна ідзе) or when i stands as an independent word. This inconsistency was introduced into Byelorussian orthography following the 1926 Academic Conference on the Reform of the Byelorussian Orthography and Alphabet. The 1930 prajekt unsuccessfully sought to resolve it by advocating the retention of both $\mathrm{y}$ and $\mathrm{i}$ in all circumstances. ${ }^{89}$ Perhaps the time has now come to re-adopt the convention of the early $1920 \mathrm{~s}$; it was, after all, good enough for Taraškievič.

89. Bielaruski pravapis (prajekt), p. 13 